\title{
Article \\ Policing Norwegian Welfare: Disciplining and Differentiating within the Bottom Rungs
}

\author{
Erika K. Gubrium * and Ariana Guilherme Fernandes \\ Institute for Social Work, Child Welfare and Social Policy, Oslo and Akershus University College, 0130 Oslo, Norway; \\ E-Mails: Erika.Gubrium@hioa.no (E.K.G.), ariana.fernandes@hioa.no (A.G.F.); Tel.: +47-22-45-35-61 (E.K.G.) \\ * Corresponding author
}

Submitted: 18 February 2014 | In Revised Form: 9 May 2014 | Accepted: 13 May 2014 |

Published: 17 September 2014

\begin{abstract}
Policing is a disciplining means for using welfare services to govern welfare recipients towards a desired behaviour or goal. We apply Foucault's (1977) definition of institutional discipline as a means for exploring how the distinctions made by state and local welfare authorities in Norway when policing recipients may take shape according to normative perceptions of ethnicity and deservingness. More particularly, we explore the regulating understandings and activities linked to the inclusion and exclusion of eligibility to welfare benefits and services and the form of the services offered. Our focus lies at the point of entry from the lowest tier of Norwegian welfare benefits (social assistance) into two semi-parallel and higher tiers promising more (higher benefits, better services). The tiers are represented by programmes that share aims, yet differ in reach: the 2004 Introduction Programme and the 2007 Qualification Programme. The Introduction Programme is an activation programme targeted at immigrants and refugees newly arrived to Norway. Its aim is to strengthen opportunities to participate in society and labour market, as well as to promote economic independence. The Qualification Programme is an activation programme that was explicitly modelled after the Introduction Programme, yet whose target group reaches more broadly to include long-term recipients of social assistance and those whose work ability is severely lowered. While both programmes have been premised on the need to transform participants from a status of passive welfare benefit recipients to active participants in qualifying measures and society, the target groups vary and it is this contrast that is our point of focus. We contrast the two policies at two 'moments' in the policy cycle: (1) policy framing (public and policymaker understandings/assumptions concerning the target group, the location of accountability for the marginal position of the policy recipient and the policy's political/social goals); and (2) the shaping and formative structure of these policies (how the relevant policies came into existence and what they look like).
\end{abstract}

\section{Keywords}

activation; discipline; ethnification; Introduction Programme; Qualification Programme; Norwegian welfare state; social assistance

Issue

This article is part of the special issue "Policing Ethnicity: Between the Rhetoric of Inclusion and the Practices and Policies of Exclusion", edited by Professor Abby Peterson (University of Gothenburg, Sweden) and Professor Malin Åkerström (University of Lund, Sweden).

(C) 2014 by the authors; licensee Cogitatio (Lisbon, Portugal). This article is licensed under a Creative Commons Attribution 4.0 International License (CC BY).

\section{Introduction}

Forty years ago, Michel Foucault (1977) traced the rise of institutional discipline as a mechanism of power regu- lating the behaviour of individuals in society. In contrast to older, harder models of punishment, discipline was a 'gentler' way of imposing control. Yet with an emphasis on social norms and the creation of hierarchical catego- 
ries of identity, its effect was to 'punish less, perhaps; but certainly to punish better' (Foucault, 1977, p. 82).

Since the rise of the welfare state in Norway in the early to mid-20 ${ }^{\text {th }}$ century, Norway's social welfare policies directed to individuals living or in danger of living in poverty have followed the trajectory toward gentle control. In what might be called the 'pre-modern' period, Norway's Poor Law of 1845 applied a 'workhouse test' that was punitive in a corporal as well as social sense. It denied help to the so-called 'able-bodied' unless they were so destitute as to be willing to accept accommodation under strict work-based regimes. As a result, they lived in conditions worse than those experienced by the poorest, independent worker (Her Majesty's Stationery Office [HMSO], 1834).

The broad extension of generous social insurance benefits characterizing the Norwegian welfare system since the mid-1930s may be termed the 'modern' period. The Nordic Welfare State Model has been characterized as having a high level of de-commodification (Esping-Andersen, 1990), universal coverage with an emphasis on full employment and equality (Korpi \& Palme, 1998), social protection as a citizenship right (Ferrera, 1996) and high, tax-based, social expenditure (Bonoli, 1997). The model has, however, come under pressure in recent decades due to Europeanization, globalization, economic crisis and demographic change (Greve, 2007; Kvist \& Greve, 2011). The structure of the welfare system itself means that, as a range of 'deserving' risk groups have been lifted out of poverty, individuals not eligible for more generous benefits have been reduced to the few who are then eligible only for social assistance (Lødemel, 1997, p. 83). ${ }^{1}$ Thus, social assistance has a residual role in the broader Norwegian social protection system.

It was only in the early 1960s that state aid to individuals living in poverty moved from an explicitly punitive system to one in which the goal was more 'gentle': the encouragement of self-reliance. Norway's 1964 Social Care Act (Lov om sosial omsorg), replacing its Poor Law, emphasized the notion of free choice in its 'help to self-help' philosophy. Since 1964, the primary rhetorical focus in social assistance has been on reducing dependency on the welfare state through the work approach (arbeidslinja). This approach ties the right to social benefits to the duty to work (Lødemel, 2001). There has been broad political consensus on the work activation approach.

The 2004 Introduction Programme was passed in 2002 by the centre-right Bondevik government (Ot. Prop. nr. 28, 2002-2003) and the 2007 Qualification

\footnotetext{
${ }^{1}$ According to Statistics Norway (2010 figures) social assistance claimants make up 2.5 per cent of Norway's population. Of this group, 39.6 per cent have received social assistance for six months or longer per year and are considered long-term recipients (http://www.ssb.no/sosind/tab-2011-12-05-07.html).
}

Programme, passed in 2006 by the red-green Stoltenberg government, explicitly drew from the strategies proposed during the Bondevik period (St. meld. nr. 9, 2006-2007). ${ }^{2}$ Both programmes have represented an offer of 'more' to social assistance claimants in terms of higher benefit levels and improved services (Gubrium, Harsløf, \& Lødemel, 2014). The terms and conditions of these programmes reflect a shift in the way that the rights and duties of social assistant claimants have been rhetorically conceptualized. A hard focus on duties through strict work requirements in exchange for benefits is 'softened' by the introduction of new rights for programme participants (St. meld. nr. 50, 1998-1999). The focus on choice, active citizenship and empowerment on the part of programme participants and on competition, efficiency, benchmarking and performance measurement on the part of the institution and service provider reflect the hallmarks of a New Public Management (NPM) approach (Torfing \& Triantafillou, 2013; Sørensen \& Torfing, 2007).

Institutions, Foucault (1977) said, effectively punish and control people through the processes of hierarchical observation, normative judgment and examination. Our working definition of policing follows Foucault's notion of institutional discipline as it is a useful way to analyse the differing regimes of control in the two policies in focus. We focus on the disciplining that takes place in determining movement from Norwegian social assistance into the two semi-parallel and higher tier Introduction Programme and Qualification Programme, as well as on the differing sorts of disciplining that takes place within the programmes, themselves. Our study of disciplining is informed by an analysis of relevant policy documents and media coverage during policy development. Our data is limited to the 'mechanisms of objectification' that are present in the framing and shape of each programme. Admittedly, this sort of 'top-down' analysis might be criticized for presenting a hegemonic view of policy, as it does not allow us to grasp the values that may affect the implementation practices, understandings and interactions between service providers and recipients (Bogason, 1991). Yet our analysis does allow us to explore the policy terrain that limits and shapes how recipients might 'constitute

\footnotetext{
2 The offer of a new work approach for long-term social assistance recipients was an easy call given the impetus for structural and strategic changes to Norway's welfare system in the early 2000s. Research had suggested that the long-term social assistance recipient population to whom the Qualification Programme was targeted suffered from a complex set of health and social issues that required programmes and services recognising that recognized this reality (van der Wel et al., 2006). The Qualification Programme's state-set benefit level answered cross-party proposals for increased state intervention into social assistance. Long- term social assistance recipients became a primary target group and labour activation measures the main instrument.
} 
themselves as subjects of moral conduct' (Triantafillou \& Nielsen, 2001, p. 66). The agency of the subject and the choices made may be limited by the understandings and moral frameworks characterising the policies offered. This, certainly, speaks to Foucault's notion of technologies of the self.

Both programmes in focus have been premised on the need to transform participants from a status of passive welfare benefit recipients to active participants in qualifying measures and society. Yet the target groups for both vary and it is this contrast that is our point of comparative focus. The Introduction Programme (2004) is an activation programme targeted at immigrants and refugees newly arrived to Norway. ${ }^{3}$ Its aim is to strengthen opportunities to participate in society and labour market, as well as to promote economic independence. The Qualification Programme (2007) is an activation programme that national policymakers explicitly modelled after the IP, yet whose target group reaches more broadly to include long-term recipients of social assistance and those whose work ability is severely lowered. The Qualification Programme target group is heavily structured by the particulars of social class, physical disabilities, as well as by dominant notions of employability and mental health problems (Naper, van der Wel, \& Halvorsen, 2009; van der Wel, Dahl, Lødemel, Løyland, Naper, \& Slagsvoldet, 2006). ${ }^{4}$ Public conceptualizations of the target group have followed suit (Gubrium, 2013). Interestingly, participation in the Qualification Programme by immigrants to Norway has been considerable (Reichborn-Kjennerud, 2009). According to a register-based survey of the Qualification Programme conducted in $2010,40 \%$ of the programme's participants were immigrants to Norway (Naper, 2010). Thus, the

\footnotetext{
3 The target group consists of people between 18-55 who are granted residency as quota refugees (UNHCR), asylum, or for collective protection, residency on humanitarian grounds, family reunification with persons in the categories above if they have been in the country less than 5 years, residency after family reunification and marriage dissolution due to forced marriage, violence, abuse, or the prospect of facing severe difficulties in country of origin upon return (Rundskriv Q- 20/2012, § 2). In the beginning of 2001 the immigrant population in Norway consisted of 298000 people or $6,6 \%$ of Norway's total population. $84 \%$ of the immigrant population belonged to the so-called 'first generation'. The unemployment rate for immigrants was $7,9 \%$ in august 2001 , compared to $2,9 \%$ in the total population ( $\varnothing$ stby, 2002). The largest immigrant groups in the 1990s were from Sweden, Denmark, Pakistan and Bosnia-Hercegovina. By 1999, the demographics of immigration had changed: of 6738 refugees who settled in Norway, the largest group was from Iraq, followed by Yugoslavia, Somalia and Croatia (NOU 2001: 20).

${ }^{4}$ The offer of a new work approach for long-term social assistance recipients was an easy call given the impetus for structural and strategic changes to Norway's welfare system in the early 2000s. The Qualification Programme's state-set benefit level answered cross-party proposals for increased state intervention into social assistance.
}

programmes may differ more in their imagined target groups than in their actual participant groups.

Social scholarship has long considered the idea that policy measures that are selective, in contrast to universal, will stigmatize claimants to various degrees (Titmuss, 1976; Pinker, 1971). Both the Introduction Programme and the Qualification Programme may stigmatize because of their selective nature, yet ethnicity and race also matter in the framing, development and design of welfare services (Fernandes, 2013; Emmenegger \& Careja, 2012; Sainsbury, 2006, 2012; Castles \& Schierup, 2010; Faist, 1995). While scholarship focused on Scandinavia focuses on the interplay between increased immigration and the changing shape of policy (Brochmann \& Hagelund, 2012; Sainsbury, 2012), it does not specifically consider the role of hegemonic understandings in these processes. The concept of ethnification helps us to understand practices and processes of domination and subordination separating those 'inside' the majority population from those 'outside', with reference to the physical/biological or to perceptions regarding cultural norms (Eriksson, 2006). Our comparison enables us to trace the connections made between ethnicity and deservingness within the lowest tiers of the Norwegian welfare system.

We contrast the disciplining and ethnification processes that occur in each programme in conjunction with the policy development of each at two levels. First, through the framing of the programmes-the public and policymaker understandings/assumptions concerning the target group, the location of accountability for the marginal position of the programme user and the programme's political/social goals. Second, through the shape of the programme-what each looks like in terms of benefits, sanctions and services. We explore and contrast how the disciplinary mechanisms enabled by the frame and shape of the programmes operate under specific ethnic norms and work to govern welfare recipients towards a desired behaviour or goal.

\subsection{Disciplining Processes}

Foucault's (1977) modern disciplinary society consists of three key techniques of control: hierarchical observation, normalizing judgment, and the examination. Institutions achieve control over people (power) by merely observing them. While the perfect system of observation would allow one 'overseer' to keep full oversight of the situation this is not usually possible. Instead, it is necessary to rely upon a hierarchical chain of observers placed at lower to higher levels through which observed information passes.

Normalizing judgment focuses on how people have failed to meet certain socially determined norms or standards. The more 'gentle' goal of the modern disciplinary system is to identify these failures in order to reform this abnormal behaviour rather than the goal of 
corporal punishment. Discipline occurs through the imposition of specified norms ("normalization"). With this process comes the institutional activity of evaluating what is and who is normal or abnormal.

The examination is a tool for putting into practice the knowledge accumulated through hierarchical observation and the normalizing judgments involved. Its first aim is to determine what those undergoing observation know, how they fit with social norms and how they may have failed on both counts. The second is to control their behaviour by forcing them to follow a prescribed course of learning or treatment.

We apply Foucault's ideas of disciplinary observation, normalizing judgment and examination and focus on how the distinctions made by national policymakers in Norway take shape according to normative public perceptions of ethnicity. More particularly, we explore the regulating understandings and activities linked to the inclusion and exclusion of eligibility to welfare benefits and services as well as the shape of the services themselves.

\subsection{Ethnification: Differentiated and Disciplined Identity}

It is a well-established finding within social policy scholarship that support for welfare benefits and/or generous benefits is closely coupled to the popular images of the target population of those receiving welfare services (Schneider \& Ingram, 1993; Baldwin, 1990). Target groups perceived to be more deserving generally receive higher support, benefits and better welfare services compared to those viewed as less deserving (Larsen, 2006; van Oorschot, 2006). Those groups considered the least 'deserving' categories within public opinion typically reflect social vulnerable groups such as the unemployed, people with disabilities and social recipients (van Oorschot, 2006, 2007; Larsen, 2002, cited from van Oorschot, 2005, p. 2; Fridberg \& Ploug, 2000). Conversely, the design of public policies themselves also shape public opinion (Mettler \& Soss, 2004). The differentiation between deserving and less deserving targets groups has led to what certain scholars refer to a 'welfare hierarchy of deservingness', between those who get better and more services compared to those who get poorer and less services (van Oorschot, 2007).

In the wake of increased immigration to Western European countries, immigrants represent a relatively new target group, and add another dimension to the differentiation of the welfare system. Studies of European perceptions of deservingness of immigrants in relation to other marginalised groups in society report that $\mathrm{mi}-$ grants are broadly considered the least deserving of all comparable groups (van Oorschot, 2005). Thus, extending the notion of a hierarchical welfare state, with increased immigration we are witnessing new distinctions with the generation of welfare dualism (Bay, Finseraas,
\& Petersen, 2013; Emmenegger \& Careja, 2012). This results in a two-tier welfare system where 'access to benefits and/or generosity of benefits is being systematically differentiated between immigrants and the general population' (Bay et al. 2013, 200). We bring in the concept of ethnification to explore how and when welfare dualism operates at the bottom tier of the Norwegian welfare system, social assistance.

\section{Methods}

We explore how policy texts and the policy development process when establishing the Introduction Programme and the Qualification Programme have differently constructed the identity of their target groups. We also investigate how the benefits, sanctions and services availed to these two target groups have differed.

\subsection{Data Sources}

We analysed primary policy documents pertaining to the Introduction Programme and Qualification Programme, respectively, with a focus on strategies underlying the reform process, the use of framing and discourse by social actors involved in this process, and the objectives tied to these processes. From Norway's reigning government (www.regjeringen.no) and parliamentary (www.stortinget.no) webpages, we obtained and analysed pertinent Norsk Offentlig Utredninger (NOUs-green papers drafted by the ruling administration and conducted by governmentappointed expert committees or commissions), Stortingsmeldinger (St. meld.-white papers that have been refined based upon public comment and which, given additional hearings, are further refined and sent to the Norwegian Parliament), Odelstingsproposisjoner (Ot. Prp-refined proposals that are to become law), Instillinger til Stortinget (Instill. St.-the Parliamentary response to government proposals), the resulting enacted laws, as well as subsequent circulars (Rundskriver) providing further specifications.

We also analysed the comments of key public political figures as reported in Aftenposten and Dagbladet, two of Norway's national newspapers with a prominent readership, using the searchable database, ATEKST. The search focused on the period from 1997-2004 (Introduction Programme) and 2004-2007 (Qualification Programme), representing the years surrounding the development of these policies. We applied a combination of search terms, many obtained during a reading of secondary texts and government policy documents. Among the primary search terms used were the names of the government officials who were key to the Introduction and Qualification Programme policies. We also conducted searches using the names of political parties and employer/employee groups in tandem with the policies and terms representing these policies. 


\subsection{Methods of Analysis}

Target group framing may shape the overall strategies aimed at a particular target group (Johnson, 2010; Loseke, 2010). In turn, employing certain 'legitimation rationales', policymakers may link these socially constructed understandings to describe the problem at hand (Bacchi, 1999, 2009) and to offer rationales as to how their favoured policies serve common interests (Habermas, 1975). In other words, policymakers use the specification, characterization and definition of target populations to legitimize (or disavow) policy rationales and tools. They frame their support for or their objections to policies on the basis of cultural tradition, social norms, or economic interests as they draw upon various discourses and attempt to persuade the public to accept their arguments (Schmidt, 2002). Rationales and tools, likewise, also further legitimize how the public at large imagines or understands these populations. Thus, a focus on social constructions helps to answer Harold Lasswell's (1936) classic question, "Who gets what, when and how".

Erving Goffman's (1974) Frame Analysis argues that individuals frame their experiences and understandings according to the meanings of particular social contexts. Although our analytical focus is on the formational terrain of Introduction Programme and Qualification Programme, we are also concerned with the social norms and institutional understandings that shape policymaking for varying minimum income replacement target groups in Norway and the definitions surrounding these policies. Our focus is on contrasting how the two programmes were developed through the discursive arguments made by policymakers. Our focus is dialectical: the thematic categories forming the basis for our analysis reflect the ideologies shaping the programmes-for example, the normative rationales behind the work approach or social inclusion. They also reflect the meanings-concerning, for example, the welfare state, social assistance recipients, what it is to be Norwegian-that are discursively produced through the shape of the policies themselves (Gergen, 1994).

\section{Findings}

Norwegian policymakers have specifically focused on the policy problems of changing demographic composition and labour market requirements over the past two decades (St. meld. nr. 6, 2002-2003). Our findings contrast the broader discourse of equality with the policing activities that regulate norms concerning ethnicity and gender as we explore who it is and how it is that particular recipients are placed and moved along the lower levels of the Norwegian welfare hierarchy.

\subsection{Problems and Solutions}

The continued function of the social welfare system in
Norway depends on the productivist assumption of an economy with high employment levels and economically active people who may need to leave the workforce for short periods due to personal circumstances. Among the main challenges emphasized by Norwegian policymakers when introducing the Introduction Programme was that refugees, more often than the majority population, relied on social benefits for their income support (NOU 2001: 20). The normative judgments of policymakers followed dominant Norwegian expectations of full employment. The welfare dependency of the Introduction Programme's immigrant target group was a social problem and represented a failure by the target group to properly integrate into the labour market and society-at-large. Policy document rhetoric focused on a movement 'from passive to active' (Ot. Prop. nr. 28, 2002-2003; NOU 2001: 20). Policymakers placed responsibility for passivity at the individual level and did not explicitly consider structural causes for immigrants' high rates of unemployment, such as changes in the labour market or potential discrimination.

As with the Introduction Programme, the Qualification Programme also was to address the problems of macroeconomic insecurity and social exclusion of its target group, here, long-term social assistance claimants (St. meld. nr. 9, 2006-2007). Relevant policy documents from the reigning red-green administration relied upon an individualized discourse to describe the factors associated with being unemployed that resulted in resource deprivation and social exclusion. Among the factors noted: "bad health limiting work function and functional ability for everyday participation'; low work experience limiting entrance to the workforce; and 'low competence'/education challenging the ability to enter the workforce (St. meld. nr. 9, 2006-2007, pp. 41-42). Opposition party leaders also used an individualized discourse and described the recipient's location outside the workforce as the core problem, with little acknowledgment of the structural factors surrounding poverty and exclusion (i.e. workplace discrimination). The leader of Norway's Conservative Party, Erna Solberg, drew from the discourse of equality and inclusion and noted that traditional class divisions were not the issue in Norway. Rather, the division was instead between those inside and outside work life (Brøndbo, 2007). Following Foucault's (1977) ideas of institutional discipline, for both the Introduction Programme and Qualification Programme the individualization of the problem to be addressed served as a rationale for the strategy of individual examination and observation (supply side focus), rather than a solution that entailed a focus on the labour market (a demand side focus).

For both Introduction Programme and Qualification Programme, the individually focused 'solution' entailed a mix of tailored programming, close follow up and a higher and standardized benefit levels. These features were to act as direct incentives for the otherwise un- 
motivated target groups to work. For both groups, services had been of poor quality due to the numerous and different actors on both local and state level who had failed to cooperate and coordinate their services efficiently. The solution for those on long-term social assistance and new immigrants and refugees was 'more requirements and better follow-up' (Brøndbo, 2007; Q-20/2012).

While the state already provided standardized indicative guidelines for entitlement levels for social assistance recipients, in practice, local municipalities had been free to determine the actual amount paid. This level had depended both upon the calculated income needs of the client and the financial resources and generosity of the particular municipality concerned (LOV-1991-12-13 nr. 81a, Sec. 5-1). Participation in the Introduction Programme and Qualification Programme shifted the expectation from one of claiming economic benefits that were discretionary in nature to the incentive of a higher, standardized rate of benefit. Both programmes offered the promise of individual tailoring and increased user involvement. The solution was to introduce a mandatory activation programme with paid work as the ultimate end goal.

The 'softer work-approach' solution of increased rights and duties began with the 1998 centre-right Bondevik White Paper on Equalization (St. meld. nr. 50, 1998-1999) and continued to have broad political support over the next decade. The political right mostly stressed 'duties', 'responsibilities' and 'new requirements'. The appeal from the left framed empowerment via 'individually tailored offers' and 'equal possibilities' (Djuve, 2011; Brøndbo, 2007; Andersen, 2006; Gjerstad, 2005). Such appeals followed social policy debates in the 1990s that had contrasted the desirability and usefulness of more active strategies over passive welfare benefits (Lødemel \& Trickey, 2001).

Ethnified norms shaped the differing ways that policymakers placed focus on the problematized individuals making up the Introduction Programme and Qualification Programme target groups. Policymakers described the broader life challenges of the Qualification Programme target group as mostly individually generated. Policymakers described the immigrant target group of the Introduction Programme, however, as individually generated but also as members of groups engaging in life practices that stood in contrast to socalled Norwegian practices and values. Immigrants and refugees were especially dependent on social welfare compared to the majority population as 'customs and traditions, or attitudes and perceptions...contributed to limiting freedom of choice' (St. meld. Nr. 49, 20032004, pp. 10-11). Moreover, the underlying assumption was based on the idea that these groups did not pull their weight in the welfare state and would rather use the welfare system than be active and contribute to the society through work participation (St. meld. nr. 49
2003-2004; NOU 2001: 20, 2001-2002;). The Introduction Programme served as a 'necessary signal effect' that these groups were to conform to the same 'ground rules that everyone had to follow' (St. meld. Nr. 49, 2003-2004, pp. 10-11; NOU 2001: 20, p. 61). As a public integration policy, the programme would clearly communicate 'democratic, gender equality and human rights values' (Forskrift, 2012; Ot. Prop. nr. 28, 2002-2003; NOU 2001: 20). The Introduction Programme curriculum for social studies included 'knowledge about Norwegian culture, understood broadly' (Forskrift, 2005). This included topics such as 'what is meant by tax-financed welfare', 'foundational human rights', as well as the importance of 'individual rights, possibilities...and contributions' (Forskrift, 2012).

\subsection{Who Deserves More?}

Prior to the establishment of the Introduction Programme, all of Norway's legal residents-including newly arrived immigrants and refugees-were entitled to basic economic social assistance if lacking basic means of survival. Economic social assistance is meanstested and granted by local authorities according to economic need in order to meet basic costs of living. There has been a high degree of local autonomy and local variation in setting benefit levels and conditions (Lødemel, 1997; Terum, 1996). These features have arguably prevented a shift to a system based on predictable and stable standards. The presence of the Introduction Programme and Qualification Programme has, however, changed the distinctions that occur within social assistance. They have created new, higher tiers based not only on need, but also on claimants' resident permit status and employability. One's ability to move into higher tiers is based on a judgment concerning what is normal for each target group. Different understandings concerning what is 'normal' for each are reflected in the examinations (or lack thereof) that are tied to determining eligibility for each programme.

The Introduction Programme target group includes newly arrived immigrants between the $18-55$ years who have a need for basic (or further) qualification. Additionally, one must also have been granted asylum on political or humanitarian grounds, a member of a group bearing a collective residence permit, or granted family reunification with persons in the categories above. ${ }^{5} \mathrm{EU}$ citizens are excluded from the group (Rundskriv Q20/2012).

Among the government rationales for the creation

\footnotetext{
${ }^{5} \mathrm{~A}$ more recent circular has added to the target group those seeking residency after family reunification and marriage dissolution due to forced marriages, violence, abuse, or the prospect of facing severe hardship in country of origin upon return (Rundskriv Q- 20/2012).
} 
of a restricted target group was that the inclusion of all immigrant groups, including those 'with higher education from the U.S., Canada and Australia', would result in the creation of a 'highly heterogeneous' target group, (Ot. Prop. nr. 28, 2002-2003, p. 48). This implies that the target group that was delineated for the Introduction Programme is, in fact, homogenous and more 'troubled' than those immigrant groups not included. This assumption is problematic for two reasons. First, the delineated Introduction Programme target group consists of members coming from at least 49 different countries (Enes \& Henriksen, 2012). This understanding is surprising, given that the large heterogeneity between different immigrant countries was, in fact, noted in early Introduction Programme policy development documents. Second, the explicit exclusion of immigrants from western countries is based on an understanding that the needs, norms and cultural background of immigrants from the U.S, Canada and Australia are more 'normal' according to prevailing Norwegian standards and that they are distinctly different from those of refugees and immigrants from outside of Europe. In fact, one policy document reported that immigrant groups hailing from Asia and Latin America had a higher labour market participation rate than the overall Norwegian population while still others-including those from North America-had a considerable lower participation rate (NOU 2001: 20, p. 26).

As with the Introduction Programme, the target group for the Qualification Programme is disparate (van der Wel et al., 2006; Naper et. al., 2009). Policy documents state that the target group is comprised of long-term social assistance claimants with 'weak ties to the labour market' and who are 'in danger of entering a passive situation characterized by income poverty combined with other living condition problems of a health or social character' (St. meld. nr. 9, 2006-2007, p. 10). Those claimants wishing to enter the Qualification Programme undergo an initial evaluation and skills mapping protocol. The mapping process is to take place 'in cooperation with the system user' and to consider 'user experiences and wishes' (Ot. prp. nr. 70, 2006-2007, p. 27). The evaluation is used to gauge whether applicants have both 'severely reduced work and income ability', yet also possess a level of ability such that the Programme could be 'helpful in strengthening the possibility for participation in work life' (St. meld. nr. 9, 2006-07, pp. 34, 224).

While the Introduction Programme target group is eligible by dint of residency status, the Qualification Programme target group is subject to an examination shaped by local norms concerning what is best for claimants and by what it means to be a full and active citizen. The Qualification Programme matches Foucault's (1977) idea of hierarchical observation: it is up to local caseworkers to gauge the 'danger of passivity' of those targeted for the Qualification Programme.
While activation itself (the disciplinary tool) occurs through national intervention, methods for defining eligibility have differed across municipalities, depending on municipal demographics and local office resources (Schafft \& Spjelkavik, 2011; NAV Directorate, 2011; Naper, 2010). This supports the argument that local welfare traditions, norms and expectations may also variably shape eligibility criteria for the Qualification Programme across regions. The need for the Qualification Programme is viewed against the backdrop of people's perceived failure to conform to societies' values and norms. Where labour market integration is a strong norm, the identities and behaviours associated with long-term unemployment are evaluated and taken as signs of disintegration. On the other hand, the state takes for granted that the Introduction Programme target group is passive.

It is notable that both the Introduction Programme and Qualification Programme have quite disparate target groups, yet it is only with the Qualification Programme that the process for determining eligibility considers this disparateness. The discretionary nature of the Qualification Programme follows a tradition that has long characterized social assistance (Terum, 1996). Yet the new system of determining eligibility intensifies the focus on the personal, as it shifts from a consideration of economic needs to a calculation of personal abilities and possibilities. And whereas eligibility to the Qualification Programme is discretionary, eligibility to the Introduction Programme is clearly formulated and narrowly defined, based on residence status. The fact that the Introduction Programme easily lumps a target population not necessarily sharing a similar history paradoxically results in its right-based eligibility process. Yet placement of this varied target group into a single category attached to a presumption of cultural marginality and passivity is likely to be stigmatizing.

\subsection{Tools for Problem Solving}

Policymakers have described the benefits and programme structures of the Introduction Programme and Qualification Programme as tools to motivate target groups to enter the labour market. The structure of each, however, reveals different understandings of the programmes' target groups.

\subsubsection{Benefits}

Both Introduction Programme and Qualification Programme participants receive a standardized benefit rate that is typically higher than that of social assistance. As opposed to tax-free social assistance benefits, the Introduction Programme and Qualification Programme benefits are taxable (Ot. prop. nr. 70, 2006-2007, p. 38; Ot. prop. no. 28, 2002-2003, pp. 9091). Policymakers based the calculation of the higher 
benefit on rational choice understandings of individual needs and motivations. For both, the policy language outlining the thinking behind the higher benefit level reflect the idea that higher short-term costs are necessary to enable longer-term financial stability at the state level (St. meld. nr. 9, 2006-2007, p. 14; Ot. prop. no. $28,2002-2003$, pp. $65-66$;). The notion of paying taxes is linked to the idea of full, active citizenship. For both, the benefits were designed to resemble an ordinary salary in working-life where participants have to 'do something, to get something' (Ot. prop. nr. 28, 2002-2003, 83). The benefits aimed to 'motivate the individual to active participation' and represented 'an incentive to move into work life' (Ot. prop. nr. 70, 2006-2007, 37). The incentive-based thinking tied to the offer of a higher, stable benefit represents Foucault's (1977) gentle form of discipline, here based on the normative expectation of full employment and social responsibility.

While the thinking related to the economic benefit level itself is similar for the two programmes, we must also consider the nature of the total constellation of benefits for each. This includes the rules for maintaining the full benefit as well as the additional economic benefits tied to programme participation. There are three ways in which the benefits packages for the programmes differ.

First, while participants in the Introduction Programme are allowed to retain their full benefit if they find paid employment, the Qualification Programme benefit is reduced to the extent a programme participant has income-earning employment. Thus, the IP benefit does not fully retain the means-tested character of the social assistance scheme. Second, as opposed to a social assistance benefit offering only a 'citizen's salary' without a 'clarification of duties and rights' (Instilling St. nr. 148, 2006-2007, p. 12), Qualification Programme participants receive a benefit that counts towards the accrual of a normal pension. This allows participants better 'predictability' in the long-term (Ot. Prop. nr. 70, 2006-2007, p. 38). Unlike the Qualification Programme, however the Introduction Programme benefit does not count toward normal pension contributions. Third, Qualification Programme participants receive a standardized benefit per child in addition to their regular program benefit, making the benefit better attuned to 'the realities of family needs and responsibilities' (LOV-1991-12-13 nr 81a, Sec. 5-9). In contrast, Introduction Programme participants do not receive an additional child benefit. This difference has been explained in policy documents. The Introduction Programme aims to 'stimulate' programme participation by 'both caretakers in the home' and to generate 'equality between the genders'. In light of this, any consideration toward extra child expenses might risk 'weakening' the target group's 'responsibilities for their own priorities and decision making' (Ot. prop. nr. 28,
2002-2003, pp. 70-71, italics added for emphasis).

The shape of the benefits attached to the two programmes reflects the normative judgments made about the target group of each. Target group constructions have shaped the strategies for solving the 'prob$\mathrm{lem}^{\prime}$ at hand. Policymakers have designed the Introduction Programme with an ethnified and essentialized understanding of its non-western immigrant target group in mind. Paradoxically, figures provided in an early Introduction Programme policy document show that employment levels for immigrants from North America and Oceania were lower than for Asia and Latin/South America. The gender division was also greater (NOU 2001: 20, p. 27). Nevertheless, it was nonwestern immigrant women who were singled out as the specific group to be targeted for the gender equality-focused Introduction Programme. Gender inequalities and a lack of women's agency were among the key problems to be addressed. Successful integration was understood as being on par with gender equality (Annfelt \& Gullikstad, 2013; Rugkåsa, 2010; Gressgård, 2005; Gressgård \& Jacobsen, 2002, 2003). This reflected an assumption that a non-western cultural background necessitated the inculcation of 'correct' western cultural norms regarding gender equality (Midtbøen \& Teigen, 2013). The constitution and representation of nonwestern immigrant women as involuntarily trapped in 'patriarchal cultures' is a reoccurring phenomenon found in official policy documents in Norway (Annfelt \& Gullikstad, 2013), and not exclusive to the Introduction Programme.

Thus, in contrast to the Qualification Programme, policymakers have applied a 'gentler' means test to the Introduction Programme so as not to create disincentives for non-western immigrant women to come out of the home to work. Furthermore, the refusal to provide extra child support to Introduction Programme participants is to ensure that the incentive will be to work rather than to have more children. There has been no provision for pension accrual because the target group lies at a lower point on the welfare system hierarchy-having not yet qualified themselves to count for minimum citizenship status and therefore not in need of provisions that provide stability for the future. The Qualification Programme benefit, on the other hand, is pension generating, comes with a childcare benefit, and is means-tested against waged employment. This reflects an understanding of the target group in which gender inequalities are not the problem, motivation to work is. The goal is to move the target group into full social participation through regular employment and to provide security for the long term.

\subsubsection{Program Shape}

In addition to the examination that takes place for potential Qualification Programme participants, an addi- 
tional tool for examination used in both the Introduction Programme and Qualification Programme is the 'individual plan'. On the one hand, the content of each programme is to be shaped 'in cooperation between the caseworkers and users' and according to a detailed mapping of participant's background (St. meld. nr. 9, 2006-2007, p. 2; Ot. prop. nr. 28, 2002-2003, p. 59). ${ }^{6}$ The plan serves as a 'welfare contract', directly connecting the rights associated with programme participation with a discrete set of duties. It is this plan that serves as the link between individual progress at the local level and the award of state-provided benefits.

In addition to shared points of examination, the Introduction Programme and Qualification Programme share similar logistical requirements and rights that simulate the contours of ordinary work life. Each programme's day resembles an ordinary workday and participants are required to engage in full-time activity on a yearlong basis (St. meld. nr. 9, 2006-2007, p. 226; Ot. prop. nr. 28, 2002-2003, p. 54). Programme participants are to receive the same vacation and leave privileges as regular wage earning workers (Ot. prop. nr. 70, 2006-2007; Ot. prp. nr. 28, 2002-2003, p. 54). The requirement of full time activity and training is designed to encourage social inclusion by providing a 'transition to work life.' The format of the programmes 'counteracts' the 'passivity' of those 'with weak connections to the labour market' (Ot. prp. nr. 70, 2006-2007, p. 11, 29; Ot. prop. no. 28, 2002-2003, p. 54).

The Introduction Programme and Qualification Programme share the same normalizing labour market aims and, in fact, participants partake in many of the same labour market-oriented measures. Yet the Introduction Programme also has additional aims related to integration. Its programmatic content is designed with the aim of teaching about Norwegian society, 'to provide basic understanding of Norwegian society life' and to contribute to 'economic self-sufficiency and selfresponsibility' (Rundskriv Q-20/2012, pp. 14, 23). At a minimum, the programme includes 250 hours of Norwegian language training, 50 hours of civic studies and measures preparing participants to assimilate into working and ordinary social life. Included in the civics course is a focus on liberal democratic values, human rights and Norwegian history. Among the listed goals in the civics course is for students to learn about Norwegian 'values', including that 'violence against children and other family members...and forced marriage are forbidden' as well as to 'discuss different perspectives on child rearing' (VOX, 2012, p. 5). Participation and completion in Norwegian courses and civic studies are a requirement for Introduction Programme partici-

${ }^{6}$ In terms of broader reform, this could represent a shift from NPM thinking to the collaborative and trust-based approach of New Public Governance (Torfing \& Triantafillou, 2013). pants to achieve permanent residence or, eventually, citizenship. This ability to sanction creates a division between who is 'in' and who is 'out' in terms of who has access to full social, economic and political rights.

Participants in the Qualification Programme are entitled to 'work-related measures and work seeking'. Other measures such as 'training, motivational counselling, skills training' are optional, as is 'time set aside for health aid, training, ability activities, etc.' (LOV1991-12-13 nr 81b, Sec. 5A-2). While the focus of the Qualification Programme is primarily on transition to work, the aim of the Introduction Programme is mainly on promoting first time labour market integration for new immigrants who have not had the time to yet establish themselves in working life. While language training is arguably a necessary ingredient for successful labour market integration, it is less clear how and why social studies training fits in with this effort. It would seem that the social studies requirement is not directly attached to employment aims. Moreover, the focus on values, violence and appropriate childrearing predicates understandings concerning the Introduction Programme target group on the assumption that many members stand in violation of dominant cultural norms.

\section{Conclusion}

We have compared and contrasted the disciplinary mechanisms enabled by the frame and shape of the Introduction Programme and Qualification Programme, as well as explored how each programme reflects varying ethnified understandings of their target groups. The following section summarizes and discusses the main findings within the context of changing forms of discipline within Norwegian activation at the lowest levels of the welfare system.

The Introduction Programme and Qualification Programme have been framed and shaped as a solution to the problems of worklessness and low social integration. The focus on divisions between those lying inside versus those lying outside work life has shifted focus to individualized problems and solutions (Daguerre, 2007, p. 7). Furthermore, and in contrast to the Qualification Programme, the problem of being 'outside' for the Introduction Programme target group is also cast as a matter of cultural difference. The individualized and ethnified casting of the 'problem' leaves us with a policy problem description that moves attention away from recognition of broader socio-structural problems.

As the problem is individualized, so is the solution. The modern, individualized strategy applies a strategy of softer, incentives-based disciplining (Daguerre, 2007; Lødemel \& Trickey, 2001), fitting with Foucault's (1977) description of institutional regimes of control. Yet, while problems and solutions are focused on the individual, they are also ethnified, representing essentialized notions of culture and the target group in focus 
(Schinkel, 2013). Differing hierarchical systems of deservingness between the Introduction Programme and Qualification Programme are revealed at the point of eligibility determination. Both programmes have established new hierarchies within the lower tiers of the Norwegian welfare system. The Qualification Programme is framed around an individual assessment tool, yet the assessment of deservingness is overwhelmingly based on work ability. The Introduction Programme is also based on work ability, yet rather than individualized, its rights-based eligibility protocol adheres to an essentialized notion of outsiderness with the inherent goal of cultural assimilation for the entire target group.

The tools for solving problems are also the tools for control and examination. The benefits structure of both programmes offers a softer means for incentivebased control. Yet while the benefits structure of the Qualification Programme allows for a more holistic consideration of the life situation of the participant, the Introduction Programme structure is more rigid to encourage/control (especially female) participant movement into the labour market and reflects essentialized understandings of the culture and norms of the target group.

Yet while the benefits offered by both programmes represent a softer means of disciplining, the shapes of the programmes reveal differing strategies for control. The content of both programmes is to be shaped according to an individual plan. The plan functions as a second tool for examination linking various levels of hierarchical observation. Both programmes reflect a strategy of normalizing discipline-with a focus on both measuring abnormality and transforming it. Yet while it is the worklessness of Qualification Programme participants that is the problem in focus, Introduction Programme participants are imagined to be troubled both in an economic and cultural sense. Thus, the Introduction Programme 'solution' also consists of a requirement for cultural indoctrination. This activity is tied to the right of residency and the threat of physical sanction harkens back to the pre-modern system of hard control. Loïc Wacquant (2011, p. 13) writes it is easier for the welfare state to introduce and uphold punitive measures in societies with a clear ethnic divisions when the measures are mainly directed at immigrants. The harsher form of control taking place within the Introduction Programme is acceptable for its immigrant target group. This dual system of control is another form of welfare dualism, now introduced through activation strategies.

It has long been recognized that selective measures may contribute to the marginalization of their target groups (Titmuss, 1976). In the last decade, activation and conditionality have indeed introduced 'softer' forms of discipline. Yet additional distinctions along ethnic lines within the Introduction Programme also illustrate movement back to slightly harder forms of control. Norway's activation strategies at the lowest tiers of the welfare system represent a dual approach, wherein culturally normative divisions enable a move away from modern discipline and may represent a newer movement back to harsher forms of examination and control. Low public support for the welfare system reportedly reflects racialized divisions in the U.S. (Larsen, 2013; Schram, Soss, Fording, \& Houser, 2009). Public perceptions of welfare deservingness in Norway and Denmark also now reflect support for a dual welfare system (Bay, Finseraas, \& Pedersen, 2013). Our article shifts focus to the distinctions taking place within the framing and shaping of activation policies themselves.

While our findings imply that the different framing and shaping of the Introduction Programme and Qualification Programme encourage recipients to 'constitute themselves as subject of moral conduct', our data only allow us to provisionally suggest how this may translate into varying 'relationships with the self', 'selfknowledge', and 'self-examination' (Foucault, 1992) for the participants of the two programmes. Still to be seen is whether the policies in practice are also (further) divided along ethnic lines.

To be sure, the programme frameworks as suggested in policy documents can only hint at the actual content of the two programmes and the interactions occurring within each. As both the Qualification Programme and Introduction Programme are provided at the local level within a country with a strong tradition of decentralized control and discretionary practice, our analysis of policy language can only speak to the moral frameworks that form the basis for the content of the programmes themselves. Future research might also explore potential sites of individual transformation: resistance, re-definition or unintended consequences (for providers and recipients, alike) at play in the real-life practices taking shape during and following policy implementation. Our analysis of the framing and shaping of the two policies has provided a useful account of the regimes of control within which active subjects-providers and recipients, alike-are encouraged to act. Interviews and observations of practices and interactions would allow fuller exploration of Foucault's notion of the technologies that act 'upon the self by the self' (Rose, 1996; Rose \& Miller, 1992).

\section{Acknowledgements}

We would like to thank four anonymous reviewers and the guest editors for highly useful and insightful comments to earlier versions of the article.

\section{Conflict of Interests}

The authors declare no conflict of interests. 


\section{References}

Andersen, K. (2006). Fattig midt i rikdommen. Aftenposten. Retreived from http://www.aften posten.no

Annfelt, T., \& Gullikstad B. (2013). Kjønnslikestilling i inkluderingens tjeneste? Tidsskrift for kjønnsforskning, 37(3-4), 309-327.

Bacchi, C. L. (1999). Women, Policy and Politics. The construction of policy problems. London: Sage publications.

Bacchi, C. L. (2009). Analyzing policy: What's the problem represented to be? Australia: Pearson.

Baldwin, P. (1990). The politics of social solidarity class bases of the European welfare state 1875-1975. Cambridge: Cambridge University Press.

Bay, A.-H., Finseraas, H., \& Pedersen, A. W. (2013). Welfare dualism in two Scandinavian welfare states: Public opinion and party politics. West European Politics, 36(1), 199-220.

Bogason, P. (1991). Control for whom? Recent advances in research on governmental guidance and control. European Journal of Political Research, 20(2), 189-208.

Bonoli, G. (1997). Classifying welfare states: A twodimension approach. Journal of Social Policy, 26(3), 351-372.

Brochmann, B., \& Hagelund, A. (2012). Immigration policy and the Scandinavian welfare state 19452010. Houndsmills: Palgrave Macmillan.

Brøndbo, M. (2007). Ønsker folket i arbeid-Høyre vil fjerne klasseskillet. Aftenposten. Retreived from http://www.aftenposten.no

Castles, S., \& Schierup, C.-U. (2010). Migration and ethnic minorities. In F. G. Castles, J. Leibried, H. Obinger \& C. Pierson (Eds.), The Oxford handbook of the welfare state (pp. 278-291). Oxford: Oxford University Press.

Daguerre, A. (2007). Active Labour Market Policies and Welfare Reform: Europe and the US in Comparative Perspective. New York: Palgrave Macmillan.

Djuve, A.-B. (2011). Introductory Programs for Immigrants: Liberalism revisited, or changing ideas of citizenship? Nordic Journal of Migration Research, 1(3), 113-125.

Emmenegger, P., \& Careja, R. (2012). From dilemma to dualisation. Social and migration policies in the "reluctant countries of immigration". In P. Emmenegger, S. Häusermann, B. Palier, \& M. Seeleib-Kaiser (Eds.), The age of dualisation. The changing face of inequality in deindustrializing societies (pp. 124149). Oxford: Oxford University Press.

Enes, A. W., \& Henriksen, K. (2012). Monitor for introduksjonsordningen 2011, Rapporter 01/2012. Oslo: Statistisk sentralbyrå.

Eriksson, M. (2006). Avvikande eller osynligrasifierande praktiker i familjerättssekreterares hantering av fäders våld. In SOU 2006:37. Om välfärdsstaens gränser och det villkorande medborgarskapet (pp. 183-216). Stockholm: Statens Offentliga Utredningar.

Esping-Andersen, G. (1990). The Three Worlds of Welfare Capitalism, Princeton: Princeton University Press.

Faist, T. (1995). Ethnicization and racialization of welfare-state politics in Germany and the USA. Ethnic and Racial Studies, 18(2), 219-250.

Fernandes, A. G. (2013). The ethnification of new social risks: Programmes for preparing newly arrived immigrants for (working) life in Sweden, Denmark and Norway. In I. Harsløf \& R. Ulmestig (Eds.), Changing social risks and social policy responses in the Nordic welfare states (pp. 189-219). Houndmills: Palgrave Macmillan.

Ferrera, M. (1996). The 'Southern Model' of Welfare in Social Europe. Journal of European Social Policy, 6(1), 17-37.

Forskrift (2005). Forskrift om læreplan i norsk og samfunnskunnskap for voksne innvandrere. 200509-16 nr. 1055. Forskrift til Introduksjonsloven. Oslo: Kommunal- og regionaldepartementet.

Forskrift (2012). Forskrift om læreplan i norsk og samfunnskunnskap for voksne innvandrere. FOR2012-04-19-358. Oslo: VOX Nasjonalt fagorgan for kompetansepolitikk.

Foucault, M. (1977). Discipline and Punish: The Birth of the Prison. New York: Pantheon Books.

Foucault, M. (1992). The History of Sexuality, Vol. 2: The Use of Pleasure. Harmondsworth: Penguin.

Fridberg, T., \& Plough, N. (2000). Public attitudes to unemployment in different European welfare regimes. In D. Gallie \& Paugam, S. (Eds.), Welfare regimes and the experience of unemployment in Europe (pp. 334-350). Oxford: Oxford University Press.

Gergen, K. J. (1994). Realities and Relationships: Soundings in Social Construction. Cambridge: Harvard University Press.

Gjerstad, T. (2005). Jeg vil være nådeløs mot dem som nekter å skrive under på en velferdskontrakt. Dagbladet. Retreived from http://www.dagbladet.no

Goffman, E. (1974). Frame Analysis: An Essay on the Organization of Experience, New York: Harper \& Row.

Gressgård, R., \& Jacobsen, C. (2002). En kvinne er ikke bare en kvinne: Kjønnsproblematik I et flerkulturelt samfunn. In C. Holst (Ed.). Kjønnsrettferdighet: Utfordringer for feministisk politikk (pp. 189-230). Oslo: Gyldendal.

Gressgård, R., \& Jacobsen, C. (2003). Questions of Gender in a Multicultural Society. Nordic Journal of Women Studies, 112, 69-77.

Gressgård, R. (2005). Sideblikk. Hva mener regjeringen med flerkulturell mangfold? Nytt Norsk Tidsskrift, 1, 72-79. 
Greve, B. (2007). What characterize the Nordic Welfare State Model. Journal of Social Sciences, 3(2), 43-51.

Gubrium, E. K. (2013). Poverty, Shame and the Class Journey in Public Imagination, Distinktion. Scandinavian Journal of Social Theory, 15(1), 105-122.

Gubrium, E. K., Harsløf, I., \& Lødemel, I. (2014, forthcoming). Norwegian activation reform on a wave of wider welfare state change: $A$ critical assessment. In I. Lødemel \& A. Moreira (Eds.), 'Workfare Revisited'. The Political Economy of Activation Reforms. New York: Oxford University Press.

Habermas, J. (1975). Legitimation Crisis. Boston: Beacon Press.

Her Majesty's Stationery Office (HMSO). (1834). Report from His Majesty's Commissioners for inquiring into the administration and practical operation of the Poor Laws. London: HMSO.

Instilling st. nr. 148, 2006-2007. Innstilling fra arbeidsog sosialkomiteen om St.meld. nr. 9 (2006-2007), arbeid, velferd og inkludering, Storting Committee on Labour and Social Affairs.

Johnson, B. (2010). Kampen om sjukfrånvaron. Halmstad: Arkiv förlag.

Korpi, W., \& Palme, J. (1998). The paradox of redistribution and strategies of equality: Welfare state institutions, inequality, and poverty in the western countries. American Sociological Review, 63(5), 661-687.

Kvist, J., \& Greve, B. (2011). Has the Nordic welfare model been transformed? Social Policy \& Administration, 45(2), 146-160.

Larsen, C. (2002). Unemployment and stigmatization: the dilemma of the welfare state'. In J. G. Andersen \& Halvorsen, K. (Eds.), Unemployment and citizenship: marginalization and integration in the Nordic countries (pp. 55-72). Bristol: The policy Press.

Larsen, C. A. (2006). The Institutional Logic of Welfare Attitudes. How Welfare Regimes Influence Public Support. Hampshire: Ashgate.

Larsen, C. A. (2013). The Rise and Fall of Social Cohesion: The Construction and De-construction of Social Trust in the US, UK, Sweden and Denmark, London: Oxford University Press.

Lasswell, H. (1936). Who Gets What, When, and How? New York: McGraw-Hill.

Loseke, D. R. (2010). Thinking about Social problems. An Introduction to Constructionist Perspectives (2nd ed.). New Jersey: Transaction Publishers.

LOV-1991-12-13 nr. 81a: Lov om sosiale tjenester/sosialtjenesteloven [Social Services Law].

LOV-1991-12-13 nr 81b: (2007 updated version): Lov om sosiale tjenester/sosialtjenesteloven [Social Services Law].

Lødemel, I. (1997). The Welfare Paradox. Oslo: Scandinavian University Press.

Lødemel, I. (2001). National objectives and local implementation of workfare. In I. Lødemel \& H. Trickey (Eds.), An Offer you can't refuse: workfare in inter- national perspective (pp. 133-158). Bristol: Policy Press.

Lødemel, I., \& Trickey, H. (Eds.) (2001). An Offer you can't refuse: workfare in international perspective. Bristol: Policy Press.

Mettler, S., \& Soss, J. (2004). The Consequences of Public Policy for Democratic Citizenship: Bridging Policy Studies and Mass Politics. Perspectives on Politics, 1, 55-73

Midtbøen, A. H., \& Teigen, M. (2013). Sosial investering i kjønnslikestilling? Flerdimensjonale perspektiver på norsk aktiveringspolitikk. Tidsskrift for kjønnsforskning, 37(3-4), 294-308.

Naper, S. O. (2010). Kvalifiseringsprogrammets deltakere: Hvor lang er avstanden til arbeidsmarkedet?. Arbeid og velferd, 3, 17-25.

Naper, S.O., van der Wel, K., \& Halvorsen, K. (2009). Arbeidsmarginalisering og fattigdom blant langtidsmottakere av sosialhjelp i 1990 og 2005. In I. Harsløf \& S. Seim (Eds.), Fattigdoms dynamik: Perspektiver på marginalisering i det norske samfunnet (pp. 80-110). Oslo: Universitetsforlaget.

NAV Directorate (2011). Sluttarapport: Implementering av kvaliferseringsprogrammet 2007-2010 (Final report: Implementation of the Qualification Program), Oslo: NAV Directorate.

NOU 2001: 20 Lov om introduksjonsordning for nyankomne innvandrere (Introduksjonsloven) Utredning fra et utvalg oppnevnt ved kongelig resolusjon 19. november 1999. Avgitt til Kommunal- og regionaldepartementet 26. juni 2001 [The Introduction Act]. Oslo: Kommunal- og regionaldepartementet.

Ot. prop. $\mathrm{nr} 28$, 2002-2003: Om lov om introduksjonsordning for nyankomne innvandrere (introduksjonsloven) Oslo: Kommunal- og regionaldepartementet.

Ot. prop. nr. 70, 2006-2007: Om lov om endringer I sosialtjenesteloven. Oslo: Norwegian Ministry of Labour and Inclusion.

Pinker, R. (1971). Social Theory \& Social Policy. London: Heinemann Educational Books.

Reichborn-Kjennerud, K. (2009). En ny mulighetbrukernes opplevelse av Kvalifiseringsprogrammet i NAV, AFI notat 11/2009. Oslo: Arbeidsforskningsinstituttet.

Rose, N. (1996). Inventing Our Selves: Psychology, Power and Personhood. Cambridge: Cambridge University Press.

Rose, N., \& Miller, P. (1992) Political power beyond the state: Problematics of government, British Journal of Sociology, 43(2), 173-205.

Rugkåsa, M (2010). Transformasjon og integrasjon. Kvalifisering av minoritetsetniske kvinner til arbeid og deltakelse $i$ den norske velferdsstaten. Oslo: University of Oslo.

Rundskriv. Q-20/2012. Lov om introduksjonsordning og 
norskopplæring for nyankomne innvandrere (introduksjonsloven) Oslo: Barne, Likestillings- og inkluderingsdepartementet.

Sainsbury, D. (2006). Immigrants' social rights in comparative perspective: welfare regimes, forms in immigration and immigration policy regimes. Journal of European Social Policy, 16(3), 229-244.

Sainsbury, D. (2012). Welfare states and immigrant rights. The politics of inclusion and exclusion. Oxford: Oxford University Press.

Schafft, A., \& Spjelkavik, $\varnothing$. (2011). Kvalifiseringsprogram met-sosialklientenes vei til arbeidslivet? In T. A. Andreassen \& K. Fossest $\varnothing$ l (Eds.), NAV ved et Veiskille (pp. 127-147). Olso: Gyldendal.

Schinkel W. (2013). The imagination of 'society' in measurements of immigrant integration. Ethnic and Racial Studies, 36(7), 1142-1161.

Schmidt, V. A. (2002). Does Discourse Matter in the Politics of Welfare State Adjustment? Comparative Political Studies, 35, 168-93.

Schneider, A., \& Ingram, H. (1993). Social construction of target populations: Implications for politics and policy. American Political Science Review, 87(2), 334-347.

Schram, S. F., Soss, J., Fording, R. C., \& Houser, L. (2009). Deciding to discipline: Race, choice, and punishment at the frontlines of welfare reform. American Sociological Review, 74, 398-422.

Sørensen, E., \& Triantafillou, P. (2009). The Politics of Self-Regulation. Farnham: Ashgate.

St. meld. nr. 6, 2002-2003: Tiltaksplan mot fattigdom. Oslo: Sosialdepartementet.

St. meld. nr. 9, 2006-2007: Arbeid, velferd og inkludering. Oslo: Arbeids- og inkluderings departementet.

St. meld. nr. 49, 2003-2004. Mangfold gjennom inkludering og deltakelse. Ansvar og frihet. Oslo: Kommunal- og regionaldepartementet.

St. meld. nr. 50, 1998-1999. Utjamningsmeldinga. Oslo: Sosial- og helsedepartementet.

Terum, L.I. (1996). Grenser for Sosialpolitisk Modernisering. Oslo: Universitetsforlaget.

Titmuss, R. (1976). Essays on the 'welfare state'. London: Allen \& Unwin.

Torfing, J., \& Triantafillou, P. (2013). What's in a name? Grasping new public governance as a politicaladministrative system. International Review of Public Administration, 18(2), 9-25.

Triantafillou, P., \& Nielsen, M. R. (2001). Policing empowerment: the making of capable subjects. History of the Human Sciences, 14(2), 63-86.

van der Wel, K., Dahl, E., Lødemel, I., Løyland, B., Naper, S.O., \& Slagsvoldet, M. (2006). Funksjonsevne blant Langtidsmottakere av Sosialhjelp. Oslo: HiO Report.

Van Oorschot, W. (2005). Immigrants, Welfare and Deservingness. Opinions in European Welfare States. CCWS Working Paper. Aalborg: Aalborg University.

Van Oorschot, W. (2006). Making the difference in social Europe: Deservingness perceptions among citizens of European welfare states. Journal of European Social Policy, 16(23), 23-42.

Van Oorschot, W. (2007). Culture and social policy: A developing field of study. International Journal of Social Welfare, 16, 129-139.

VOX (2012). Læreplan i norsk og samfunnskunnskap for voksne. Oslo: VOX Nasjonalt fagorgan for kompetansepolitikk.

Wacquant, L. (2011). The wedding of workfare and prisonfare revisited. Social Justice, 38, 1-2.

$\emptyset$ stby, L. (2002). The demographic characteristics of immigrant population in Norway. Reports 2002:22. Oslo: Statistisk sentralbyrå.

\section{About the Authors}

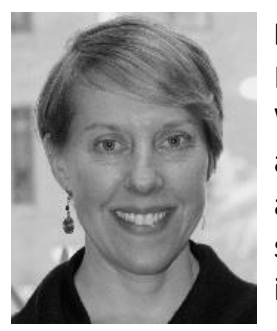

\section{Dr. Erika K. Gubrium}

Erika K. Gubrium has a PhD in Social Foundations of Education and is research leader at the Social Welfare Research Centre at the Institute for Social Work, Child Welfare and Social Policy at the Oslo and Akershus University College, Norway. Her research applies qualitative approaches to investigate anti-poverty policies in Norway, with a particular focus on discourses, norms and expectations surrounding both social assistance provision and the work activation approaches directed towards individuals receiving social assistance.

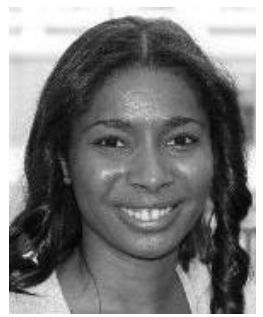

\section{Ariana Guilherme Fernandes}

Ariana Guilherme Fernandes is a PhD fellow at the University of Gothenburg at the Institute of Social Work. She is affiliated with the Social Welfare Research Centre, Oslo and Akershus University College in Norway and the Nordic Centre of Excellence, Reassessing the Nordic Welfare Model (REASSESS). Her research interests includes comparative integration policies and activation policies. Her latest publication is on Ethnification of New Social Risks: Programmes for Preparing Newly Arrived Immigrants for (Working) Life in Sweden, Denmark and Norway (2013). 